\title{
Sailing to Byzantium and Byzantium of W. B. Yeats - A Symbolical Viewpoint According to the Creation of Primal Elements
}

\author{
Brikena Smajli \\ Albanological Studies Center, Albania \\ E-mail: brikenasmaji@gmail.com
}

Doi:10.5901/ajis.2012.v2n4p223

\section{Abstract:}

Two well-known poems of W. B. Yeats are seen here in a specific perspective of Creation primal elements (earth, water, air, fire) by a symbolical point of view. Certainly, there are different interpretations of these poems, where symbolic point of view is fundamental. The very symbols which interpretation/ analyses focus on are sailing (travelling) and city (Byzantium). Through our interpretation we use to move forward: There is a fore text according to which author uses to construct/create a poem, being and feeling himself as a creator (author). According to this creative thought he move structurally and mentally travelling (sailing) to the city of a mystical significance, Byzantium (New Jerusalem) through which he try to evoke symbolically/poetically Revelation and be part elementarily with Creation of Bible, that is to say: he creates a poetry with a the creation/poetry aim to be structurally and ideally well ordered and harmonized as Creation is. In this point of view the Creation is as a fore text, structurally and symbolically organized, perfectly as it is a work of God. Moving through this perspective and seeing the creation as a work of Creation, aiming to be part of, it is the perplexity of the poet himself as a creator, maker (poet). This interpretation points out the interrelation of a poet (maker, creator) with the Creator/ God and the poesy (making, creation) with Creation and the role of the quest for the poet, symbolically expressed through a journey.

Key words: elemental symbol, hermeneutical interpretation, quest, Creation, mythocritique.

What is the poetical aim of a poet?

What does poetry mean to a poet too?

The existential poetical point of view of poetry and the poet is explained here by the two poems of W. B. Yeats. First of all, a poet is mean to be a creator, a maker; terminologically and conceptually. (Cuddon, J. A. $1998,678)$ The main structures of his thought through which does the poet operate, are that who claim to be fundamentally creative to creator.

The main concept and thought of a creator is based on the myth of Creation/ myths of Creation. The creation myths are seen here as part of inner structure of Yeats poetry, that is to say: the inner reading of this poetry need to employ this compound reading.

Sailing to Byzantium was written in 1927, at a time when the author was just Nobel Prize winner (1923) and was the most known poet of English poetry. This is the reason that the poem show the true visionary quest of the poet's art and it is, at the same time, symbolic and visionary. Written after his other work in prose, $A$ Vision, the poem need to be seen according to the symbolical system of moon explained there. There are of course the moon, sun, Byzantium, sailing, symbols which have their fore text and explanation. In relation to the poem Sailing to Byzantium there is the other poem Byzantium also, which is published only 3 years after, in 1930. The two poems need to be read in correlation, as they both symbolically stress the same idea: the quest of an artist for the eternal art.

In the type of the quest to which the author is going to inaugurate Byzantium is an "Eden" in earth and the symbol of a "New Jerusalem" for it, connect the image with the vision of an ideal city for the spirit and art, according to the mythical moon system of Yeats to the $A$ Vision. In this poem we see the mythical symbols of Genesis/creation and that of Revelation appear undersigned the obvious part of the poetry. English studies use to analyse the poetry according to the two mythic symbols: Byzantium and Sailing, connecting it with the 
mythical lunar system of Yeats, with which the poems do coincide, not only by the point of view of a place of life of the spirit after death, to which Yeats would be a visitor as a spirit or a new possibility of life, but it coincide with that phase of human history, where spirit rules, in front of full practical nature; a period of spiritual quest and of the prophets. (W. B. Yeats. A Vision, 1975, 183)

Here, going in deep, we move forward and through the interpretation of the structure of poetry, based on the elemental symbols of Creation, according to the symbolic poetic of evocation and imaginary by French Symbolism myth of the fall of man, Yeats, now old aged, is seeking to realise his aim: the quest, the poetic highest aim - eternal and immortal art.

The elemental symbols of water, air, earth and fire are part not only of structure of the Genesis/ Creation suggesting poetic rewriting on Creation, through creation (poetry), but they are elemental classical symbols of European philosophy, as they are shown to Empedocle or later on to Lucretius work. This correlation through his poetry for Yeats to Bible, Genesis and Lucretius and Empedocle (Empedocle, 1908, 17; Lucretius, 2001, 705-725) vision of creation has to do with the manner how he sees the religion: knowledge where is melted together religion, the belief on magic and scientific knowledge.

Yeats at that time old aged, think of the end, death, and artistic creation, immortality through it, otherwise the evocation of Revelation (the apocalypses of St. John) is motivated, according to Yeats who thought on Byzantium as a New Jerusalem a place stranger for the life, fenced from the alive life, (Yeats, A Vision, 1975, 288) Moreover Yeats aim the byzantine art, concretely oriental poetic, leaning to the sameness, melting, avoiding the individual and stressing the universal, as he aim with this art the Heavy, the Devine. (Franc Kermode, 1961, 124-25)

For this reason it is seen by Yeats as an earthly Eden and a place of spirit after death. By the point of view of art it is the ideal place for the artistic quest. There is of course the symbol of a city (mythical city) and that of sailing. Seeing Byzantium as a New Jerusalem or a New Rome, as it was constructed we need to read the poem according to the text of Bible, Revelation and the symbols taken there and Creation of Genesis. However to this symbolism we add even the symbol of a city as temple explained by Fray (Northrop Fray, $1990,194)$ and the symbol of sailing, from which the other symbols of water, fire, air, earth, golden bird out of fire are reorganized poetically without losing the traditional significance symbolically. In the now reorganised reading of symbolism we see the poem of biblical intertextuality. Yeats reveals us a spiritual journey/sailing. Seeing this by the Revelation point of view, we emphasise that the poems are written in a just period of time, when an old aged man think of the end of life, that is to say the Revelation also for a creation. Yeats was at that time 62, 65 years old and he is preoccupied of the age, old age, the world, success, the end, and conclusion. The first lines who open the poem written in 1927 are:

\begin{tabular}{|l|}
\hline That is no country for old men. \\
\hline An aged man is but a paltry thing .... \\
A tattered coat upon a stick... (Yeats, 1974, 104) \\
\hline
\end{tabular}

In correlation with the symbol of Byzantium, as temple, new one (New Jerusalem or New Rome), there is a journey/ sailing toward it, which suggest another interpretation, that of the quest. This last linked with the archetypal symbol of water, bear suggestions of Great Flood or Apocalyptical one, human life, a state of chaos or of tousle that follows after an ordinary death (Fray, 1990, 201) and the universal mind, eternal, unlimited, always in motion. Metaphysical Bible Dictionary, 838) So the journey of Yeats is a kind of eternal journey to the death (dark), but it is at the same time, a knowledge journey from dark of earth to the light of sky, from the ignorance to knowledge and from death to immortality. While the symbol of earth, air, and the golden bird, out of fire interconnect organically and significantly, as all they express responds not logically to their establishment in nature. So the bird is not true, it is one of the wonders of magic, made by fire, prepared by a master blacksmith, more a product of artistic creation, rather than nature, it has to do not only with air, but even the earth (blacksmith's made) and fire, as immortal monuments to which Yeats is longing for, not as a guest, but as a dead person, who will fill the thirst for knowledge and Knowledge. Motivated as a 
journey/sailing/quest, that from Ireland (1927) to mythical Byzantium, meanwhile it is a reassessment of the Revelation symbols: city, man, Devine, water, fire,( Bible, Revelation) interpret them artistically in function of this mythical sailing as a symbol of authorial, poetic, human quest - a journey, a departure as basic mytheme of hero myths.( Propp, 2004, 46) As it is known in the narrative discourse, the journey/sailing has its real artistic approach, but in the poetic text of Yeats the journey/sailing is not of this type. It is all unreal, constructed in another level of perception: not of earthly, it aims as writing art, heavenly high, therefore operates and express to the imaginary level, symbolic one, from which the journey/sailing to the other world, even shifting from the Ireland, a notion just established is a mythic journey/visionary dantesque sailing from the hell to heaven.

In favour to this interpretation comes an approach New Jerusalem - Byzantium. From there, as a New Jerusalem is only a pure soul, because it has reached the spiritual highs (lamb's bride) see: Revelation 21:9. Yeats asks to die or see himself as worthless also unaccepted in a city such as "aged man", "paltry thing" " $A$ tattered coat upon a stick", "a dying animal"(Yeats, 1974, 104)

The youth people being the contrary to the author's age are "dying generation" also.(Yeats, 1974, 104)

Everything the author leads us to believe is a contradiction in the body and spirit where the city of Byzantium is the soul receiver. Meanwhile the interrelation created by The young ...,birds in the trees..., the salmon falls, ... seas, fish, flesh,... (Yeats, 104) alive, b.s ) are of earthly temporality. Yeats does not look with any envy these people of Byzantium and a line after, he reveals the aim: "Monuments of unageing intellect." "Nor is there singing school, but studying/ Monuments of its own magnificence" (Yeats. 1974, 104)

If we try to find for each image and symbol of poetry its fundamental components respectively, we can see how structurally and semantically the symbols operate in this poem.

The first stanza there is organized on functional contrapositions, doubles or triples. Thus we have: the old man-the young man; life-death; body-soul, which are self sufficed with other contrapositions the old man "The young/In one another's arms" (human, earth), "birds in the trees" ( birds, air), "the salmon falls" (fishes, water), "seas"(water), , "the mackerel crowded /Fish, flesh, or foul,... sensual music" (Yeats, 1974, 104) Finishing then in another contraposition, that of Life- Death.

Whatever is begotten, born, and dies. Where to this last, to death, there are only Monuments of unageing intellect.(Yeats. ibid) saved.

According to this elemental analysis the second stanza (Old man-Young ) becomes The old man ( body- soul)

So: An aged man is but a paltry thing,

A tattered coat upon a stick, unless

Soul clap its hands and sing, and louder sing

For every tatter in its mortal dress,

Structurally there is another contraposition, that of death-life; as the contrariety of singing - studying in: Nor is there singing school but studying- leads us to knowledge. And Monuments of its own magnificence; Yeats, 1974, 104) are seen here by the old man point of view.

Now we can see that the point of view we use to deconstruct the Yeats poetry through symbols and the fundamental elemental components of creation (earth, water, air, fire). So, in this sense, the interrelation of external symbolism accompanied by the fundamental components, basis of creation, and the four classical elements of European philosophy also, on which the poetry is created.

According to this, the third stanza is organized as such.

Third stanza:

The old man- death

Heart (disease-desire), man - eternity

Body-soul

Where the most foundamental are two:

1. Old man-death 
2. Human -eternity

The old man leaves testament his soul, while he pleads to the sages standing in God's holy fire

....be the singing-masters of my soul. (Yeats, 1974, 104)

Where there is for the first time the appearance of fire, as an element of creation.

Consume my heart away; sick with desire

And fastened to a dying animal, (Yeats, 104)

This creation scheme of poem coincide with the creation

...be the singing-masters of my soul. (Yeats, 104)

Where there is for the first time the appearance of fire, as an element of creation.

Consume my heart away; sick with desire

And fastened to a dying animal, (Yeats, I. 21-22)

1 In the beginning God created the heaven and the earth. 2 And the earth was without form, and void; and darkness was upon the face of the deep. And the Spirit of God moved upon the face of the waters. 3 And God said, Let there be light: and there was light. 4 And God saw the light, that it was good: and God divided the light from the darkness. (Genesis, 1-4)

The scheme of Genesis we can sign here:

1. Heaven, earth

2. Earth (water) -Spirit of God

3. Earth, light

4. Light (day-night)

A comparison between this to schemes distinct a difference:

1. Heaven/air

2. Earth/earth

3. Water/water

4. Light/ fire

Between the Genesis and the inner structure of poem there are differences, as it is not created a creation, as it is not fulfilled, the author's quest for an immortal art and the eternity through it.

Therefore, the poem, suggesting Genesis, suggest to us the Revelation also, where the fire is an important part of its symbolism. However, there is important to emphasise that light and fire are divine attributes and the Spirit of God is the main Force for the Creation. The Creation in itself is thanks to the God's Will.

If Yeats structurally moves toward to this kind of creation he, therefore, expresses it through A Vision, where Sailing to Byzantium and Byzantium are part of his mythical system.

If in the first poem Yeats is sailing toward a city, mythical one, Byzantium of that time can be seen as a city of 15 Phase, according to the mythical system and it is characterized by pure subjectivity.

The individual, author and his poem suggest an experience of spiritual life after death.

If the first poem Yeats emphasise Sailing to... as a transcendental journey the second poem need to be the city in itself, mythical and completely spiritual that is to say: Yeats try to reach his poetical aim. In this perspective the first poem can be seen as indefinite journey, as it remained of earthly type, not spiritual.

In fact, in the second poem Yeats got another try to achieve his main goal. 
According to the second poem, we move to a complex of symbols linked with Revelation, but also with Genesis.

First of all, Byzantium moves ahead to the spiritual world of mythical Byzantium. The poem has five stanzas and in comparison with the first one, it completes the four elements of creation with the fifth one, which can be the Spirit of God, as in Genesis or Love and Hate as in Empedocle's creation. There are of course the four elements of creation, as fundamental components of the imagery, but there is a creature as a song bird, but part of Greek goldsmith creation, not of nature, symbol of art and made of gold, symbol of eternity.

This poem is intended to focus on the spiritual rather than earthly. In fact, this shift coincides with less room for nature images, images that are completely avoided in the fifth line.

\author{
The unpurged images of day recede; \\ The Emperor's drunken soldiery are abed; \\ Night resonance recedes, night walkers' song \\ After great cathedral gong; \\ A starlit or a moonlit dome disdains \\ All that man is, \\ All mere complexities, \\ The fury and the mire of human veins. (Yeats, 1974,153)
}

Since here the interrelation with the fundamental components, earthly images move high to the spiritual; from earth to the heaven and sea, not as earthly part, but of after life, that suggests an Eden, a mythic city.

In this point the quest is heavenly. The poet himself now moves toward the spiritual mind and imagery. This quest, according to the sailing as a symbol of transcendence is associated with the symbol of Great Cathedral, which is not only a suggestion to the Hagia Sophia Cathedral only, but it, means also Holy Wisdom. Michael Angold, 2002, 2)

And this cathedral, Holy wisdom is the symbol for the city of Byzantium too, as Holy city, a myth. It remains in the image, as myth for Yeats for it is transformed after the ottoman occupation (Byzantium was transformed to Istanbul and St. Sophia in a Mosque).

Its meaning is of course a symbolic and mythic one, representing the city, the temple, as apocalyptical symbols. (Fray, 1990, 199)

Moreover, here in "A starlit or a moonlit dome disdains/ All that man is..." Yeats reveals the city and the cathedral as completely spiritual, as it disdain the entire human. He is writing of the Byzantium of the 1 and 15 phases when there is full moon and dark moon, which is characterized by pure objectivity and pure subjectivity that mean no human, can be part of. The cathedral cannot represent the earthly build, but the heavenly one, the holy temple that starlit (dark moon) and moonlit (full moon).

Therefore, in the first stanza, although author speaks for this Byzantium of pure subjectivity (phase 15), it disdains at the first lines the earthly images; human made of flesh: The fury and the mire of human veins. (Yeats, 1974, 153)

The image of cathedral, its gong, the chapel, should bring in mind the solemnity and the wonder which is in the mind of the visitor of seeing for the first time this cathedral, its handiwork, and its architectural wonder toward the dome. It is in itself the immortal work of art for the Yeats of the first poem; it is the Idea, Love, the immortal monument, and the temple of the New Jerusalem, according to which it is associated with the typical symbols of fire and sea, as in Bible, Revelation.

Here the spiritual word of Byzantium goes on a sea where is the poet himself. Sailing as a symbol of the quest and "winding stars" as symbol of deepness and highness give to the poem the just image. The process of sailing never occur in the reality of the poem, nor it is described as such. It is a visionary sailing, therefore the sea is no more as in Bible and has to do with the spiritual sailing to the sea of afterlife, sailing that is associated with the symbol of water and that of heavenly fire as purgatorial purifying or that of shade and the mouth without breath of another spirit. The artefact displayed there in the third stanza as: 
Miracle, bird or golden handiwork,

More miracle than bird or handiwork,

... by the moon embittered. (Yeats, 1974, 153)

(here the dark moon) should be seen in correlation with the vision of the St. Sophia cathedral and its real complex meaning. (Mark, Robert and Çakmak, Ahmet S. 1992).

The fouth stanza got for the first time the appearance of fire, but here it is not the temporary, earthly human fire, it is "flames begotten of flame".

The fifth stanza turn back to the sea, not to the earthly one, but to the symbolic-mythic sea, associated with the idea of profoundness, of flood, that of dolphin in whose back the souls are carried, one by one and the fire of smithies, that it is linked with the alchemy of creation.

All of them compose the alchemy of Creation/creation and corresponds to a poet spiritual quest after death, to the ideal place of the earthly quest for him: Byzantium, and its famous Cathedral ( the Holy Wisdom Cathedral), the wonderfully art which is in it ( the construction, art's work who do decorate it, the decorated marbles, mosaics, masterful works of gold made by the Greek goldsmiths in the golden smithies of Emperor) Al of those are of divinely inspiration and immortality giver through art.

The poem in its main imagery can be structured as such:

The title:

Earth (city, Byzantium) - heaven (Byzantium)

Stanzas:

1. Earth/air, heaven

2. Sea, the spirits

3. Art, golden bird (fire)

4. Fire

5. Sea, fire, art

Byzantine historical images bring a spiritual journey background after the life going toward the sea over the dolphins back. Byzantium.

The journey begin with the ancient city, while in the first poem is was part of a journey from Ireland to

The sea here is a complex symbol, so the journey or sailing on it is a death journey, a dangerous one or the quest journey. The road of spirit after death is associated with the images of Revelation for the sea:

1 And I saw a new heaven and a new earth: for the first heaven and the first earth were passed away; and there was no more sea. (Revelation, 21.1) sailing, as:

The poem is speaking about this sea who is the receiver of spirits which is suggested in this strange

Before me floats an image, man or shade,

Shade more than man, more image than a shade.

The man, his spirit is of Astraddle on the dolphin's mire and blood, (Yeats, 1974, 153)

In oreder to reach the sea of

That dolphin-torn, that gong-tormented sea. (Yeats, 1974, 153)

So the sea is conceptually: 
1. The profound place, the spiritual journey place Where it is the image of spirits and spirit. Before me floats an image, man or shade.

2. The place where dolphin lives and this is the symbol of spirit and wisdom.

3. The meeting place of dolphin and spirit and that of the sea which is no more. ( see Revelation, 21.1)

For this reason the symbol of Byzantium according to the first poem is spiritual. The earthly Byzantium is substituted with that of emperor's army: The Emperor's drunken soldiery are abed; (Yeats, 153) and the artistic creation: golden bird with the

Marbles of the dancing floor. The earthly Byzantium is not more; instead of it is a heavenly imagery of it, dominated by fire and sea.

The sailing is no more a journey to a city, the poetic voice reached it in the first poem, and the city is not the same.

2 And I John saw the holy city, new Jerusalem, coming down from God out of heaven, prepared as a bride adorned for her husband. (Revelation, 21.2)

It is not more a city populated by young people or dying people, but of spirits carried on the back of dolphin.

The poem can be read also in the perspective of Revelation where it is a symbolism of earth, heaven, sea and fire. (Revelation 20 (11-15) and 21 (1-8)

3 And I heard a great voice out of heaven saying, Behold, the tabernacle of God is with men, and he will dwell with them, and they shall be his people, and God himself shall be with them, and be their God.

4 And God shall wipe away all tears from their eyes; and there shall be no more death, neither sorrow, nor crying, neither shall there be any more pain: for the former things are passed away.

Yeats is seeking the immortality through an art of the most spiritual value, of golden smith, through a miracle (not of skill) of its alchemical processing. Here comes the golden bird, made of emperor goldsmith, result of divine inspiration of artists. Therefore, in addition to the first verses of the poem, the human being and the earthly are no more.

Everything mentioned after: the mosaic, the golden bird, the cathedral of emperors palace are part of this holy heavenly spirit as it is the description of New Jerusalem in Bible, splendidly, shiny, by crystal, topaz, chalcedony, emerald, sardonic, etc.

This can be seen by the symbolic structures comparison between the two poems also:

Water $\rightarrow$ earth (title)

Stanzas:

1. Earth, air, water

2. Earth, water, earth

3. Fire (as a desire), earth

4. Earth, fire (as a desire)

Earth (city, Byzantium) - heaven (Byzantium)

Stanzas: 
1. Earth/air, heaven

2. Sea, the spirits

3. Art, golden bird (fire)

4. Fire

5. Sea, fire, art

The difference between these two poems argument the idea expressed before, that of a fifth element of Creation: Idea, Spirit of God, Love. To this it corresponds with the golden bird.

Miracle, bird or golden handiwork,

More miracle than bird or handiwork,

Planted on the star-lit golden bough, (Yeats, 1974, 153)

Here this golden bird is the symbol of artist and the work of art, as it is known the bird is the ancient image of spiritual. Moreover as of gold made, symbol of eternal and immortality, it is the masterpiece of an artist, spiritual one, inspired by the Creator/God. Therefore Yeats calls it More miracle than bird or handiwork, therefore it is linked with the Idea, The Spirit of God, Love and the element of fire is divine attributed and present.

\section{References}

Angold, Michael. (2002). Byzantium, The Bridge from Antiquity to the Middle Ages, Phoenix Press, London.

Brooks, Cleanth. (1965). Modern Poetry \& Tradition, A Galaxy Book, New York.

Empedocle, (1908). The Fragments of Empedocles, translated into English verse by William Ellery Leonard, Kegan Paul Trench, Trubner \& co, LTD, London.

Fraj, Northrop. (1990).Anatomia e kritikës, Rilindja, Prishtinë.

Kermode, Frank. (1961). The Romantic Image: Routledge \& Kegan Paul Ltd, London and Bradford.

Lucretius Carus, Titus. ( 2001). [De rerum natura. English version The nature of things] Lucretius; translated with introduction and notes, by Martin Ferguson Smith.

Mark, Robert and Çakmak, Ahmet S. (1992). Hagia Sophia from the age of Justinian to the present. Cambridge, New York.

Metaphysical Bible Dictionary, Charles Fillmore Reference, Libray Series.

Propp, Vladimir. (2004). Morfologjia e përrallës, Aleph, Tiranë.

Yeats, W. B., (1975). A Vision Collier Books/MacMillan, London,.

Cuddon, J. A. (reissued by C. E. Preston), (1998).The Penguin Dictionary Of Literary Terms And Literary Theory, fourth edition, Penguin books.

The Holy Bible,(1999). King James Version. New York: American Bible Society.

Plato, (2007).Timaeus, The Complete Plato, Translator: Benjamin Jowett, Adelaide books.

Yeats, W. B.(1974). Selected Poetry, Macmillan, London.

Ross, David A. (2009). Critical companion to William Butler Yeats: a literary reference to his life and work, Facts on File library of world literature, N. York.

Yeats, W.B. (1975). A Vision, COLLIER BOOKS, Macmillan Publishing Co., Inc, New York.

Wilson, Edmund, (1931). Axel's Castle; A study in the Imaginative Literature of 1870-1930; New York. 